\title{
Dairy Production in Ethiopia - Existing Scenario and Constraints
}

\author{
Mebrate Getabalew $^{1}$, Tewodros Alemneh*2 and Dawit Akeberegn ${ }^{3}$ \\ ${ }^{1}$ College of Agriculture, Department of Animal Science, Debre Berhan University, Ethiopia \\ ${ }^{2}$ Woreta Town Office of Agriculture and Environmental Protection, South Gondar, Ethiopia \\ ${ }^{3}$ Debre Berhan City Municipality Office, Meat Inspection and Hygiene, North Shewa, Ethiopia \\ *Corresponding author: Tewodros Alemneh, Woreta Town Agricultural Office, S/Gondar, Ethiopia
}

ARTICLE INFO

Received: 唪 February 25, 2019

Published: 幽 April 04, 2019

Citation: Mebrate Getabalew, Tewodros Alemneh, Dawit Akeberegn. Dairy Production in Ethiopia - Existing Scenario and Constraints. Biomed J Sci \& Tech Res 16(5)-2019. BJSTR. MS.ID.002903.

Keywords: Smallholder Farmers; Dairy Products; Artificial Insemination; Veterinary Services

\begin{abstract}
Ethiopia has the largest inventory of livestock in Africa. However, its productivity and commercialization remains low. This is after decades of interventions by the government and international donor agencies to improve the sub-sector. Recent research found that the Government of Ethiopia (GOE) has undervalued the contribution of ruminant livestock production to gross value of ruminant's contribution to agriculture. The dairy sub-sector contributes $63 \%$ to the total value of ruminant output. By underestimating livestock's contribution, the GOE has underfunded the development of this sub-sector. Recent figures indicate that the livestock sector contributes about $12-16 \%$ of national GDP, $30-35 \%$ of agricultural GDP, $15 \%$ of export earnings and 30\% of agricultural employment. Smallholder farmers represent about $85 \%$ of the population and are responsible for $98 \%$ of the milk production. Productivity however is relatively low, quality feeds are difficult to obtain and support services are inadequate.

There is an immediate and growing shortage of dairy products in all major cities of Ethiopia and the trends of economic prospects for dairy industry performance and development are rather good both at small holder and on more commercial levels. There are different constraints affecting milk production potential of dairy cattle in most parts of Ethiopia including shortage of grazing land, disease and parasites, shortage of land for cultivation of improved forage, inadequate veterinary service, low milk production potential of local zebu cattle, inadequate Artificial Insemination (AI) service and labor shortage. In order to alleviate the aforementioned constraints, increasing efficiency of AI services, improvement of veterinary services, introduction of improved forage crops and fodder trees are important.
\end{abstract}

\section{Introduction}

Dairy production is one of the major sustenance factors for the rural economy of Ethiopia. Ethiopia holds large potential for dairy development due to its large livestock population, which comprises 59.5 million cattle, 30.70 million sheep, and 30.20 million goat populations [1]. Given considerable potential for smallholder income and employment generation from high-value dairy products, development of the dairy sector in Ethiopia can contribute significantly to poverty alleviation and nutrition in the country. Different classifications have been used to characterize the dairy production system in the country. Based on their locations
[2], classified into three broad categories; namely, urban, periurban and rural dairy production system. Among the existing production systems, the traditional dairy production system is the one involving from smallholder dairy farms. The traditional (smallholder) milk production system, which is dominated by indigenous breeds, accounts for about $97-98 \%$ of the total annual milk production in the country [3]. Over $85 \%$ of the milk produced by rural household is consumed within the producer households with the proportion marketed being less than 7\% [4]. The small amount of milk produced by a large number of producers but 
the low marketable output in Ethiopia possess limitations on the possibilities of exploiting distant but rewarding markets due to high opportunity costs of labor involved [4].

As dairy production in Ethiopia is constrained by several factors classified as: Technical or biological, socio-economic and institutional factors and others some of the major environmental constraints such as low rainfall, high temperature and low forage production, common plant association, livestock and human carrying capacity, incidence of important livestock diseases and parasites, mainly define in the lowland part of Ethiopia [5]. There are a number of challenges and bottlenecks limiting the success and profitability of household dairy production systems in Ethiopia. Therefore, a comprehensive literature review on the current status of dairy production system in the country seems to be appealing. There is a need for reviewing the production system, production performance and constraints of household dairy production. Moreover, information's on either weak sides or the success stories of household dairy production including its marketing and constraints could be used by beneficiaries. It is a major contributing factor to the livelihood of resource poor subsistence farmers in a number of ways: income from milk and milk products, insurance against draught, emergency cash requirements, household nutrition, fuel for cooking, manure for crops, draught power for farming etc. Therefore, the objective of this review is to assess the current dairy production system in Ethiopia and future prospects.

\section{Ethiopian Dairy Sector}

Existing Scenario: There are 10 million dairy cows in Ethiopia producing approximately 3.2 billion liters on average of 1.54 liters per cow per day over a lactation period of 180 days [6]. The farm-level value of the milk is an estimated Birr 16 billion. The values of other important animal products and services include blood, traction, transport, and manure for organic fertilizers and fuel. Estimated calf consumption and wastage of milk is $32 \%$ of the milk produced [7]. Households consume approximately $85 \%$ of the milk collected, $8 \%$ of the milk is processed into products with longer shelf life, and 7\% is sold [8]. During peak production in the wet seasons, rural farmers, not part of formal cooperatives, face challenges marketing their milk as most regions experience a surplus. More surplus milk may be processed at the home into local cheese or butter. For most subsistence farmers in all cultures in Ethiopia, the daily decision on how to allocate milk is decided by the head female in the household and is dependent upon season, number of children in the household, presence of sick family members, and daily financial needs [6]. Ethiopia holds large potential for dairy development. In addition, the country enjoys diverse topographic and climatic conditions favorable for dairying. These consist of a high central plateau ranging from 1,800 to 3,000 meters above sea level, a rift valley that divides the country from north to south with altitudes ranging from 1,000 to 1,800 meters above sea level and lowland plain areas of less than 1,000 meters above sea level in altitude.
Depending on the altitude difference, temperature ranges from less than $10^{\circ} \mathrm{C}$ in alpine areas to $35^{\circ} \mathrm{C}$ and more in lowland areas. Moreover, rainfall in most of the country is adequate for crop and pasture production. The favorable climate throughout the country supports use of improved, high-yielding animal breeds and offers a relatively disease-free environment for livestock development. Given the high potential for dairy development and the ongoing policy reforms and technological interventions, success similar to that realized in the neighboring Kenya under a very similar production environment is expected in Ethiopia. The Ethiopian highlands possess a high potential for dairy development. They occupy the central part of the Ethiopia, cover over $40 \%$ (approximately 490, $000 \mathrm{~km} 2$ ) of the country area and are the largest of their kind in Sub- Saharan Africa. In the highland areas, the agricultural production system is predominantly subsistence smallholder mixed farming, with crop and livestock husbandry typically practiced within the same management unit [2].

\section{Rural Household Dairy Production System}

Rural dairy production system is part of the subsistence farming system that contributes up to $98 \%$ of the total milk production of in Ethiopia, and includes pastoralists, agro-pastoralists, and mixed crop-livestock producers [9-12]. The system is not market oriented and most of the milk produced in this system is only for home consumption [2]. The level of milk surplus is determined by the demand for milk by the household and its neighbors, the potential to produce milk in terms of herd size and production season, and access to a nearby market. The surplus is mainly processed using traditional technologies and the processed milk products such as butter, ghee, ayib and sour milk are usually marketed through the informal market after the households satisfy their needs [13].

\section{Per-Urban or Small Scale Dairy Production System}

Per-urban milk production system is developed in areas where the population density is high and agricultural land is shrinking due to urbanization. It possesses animal types ranging from $50 \%$ crosses to high grade Friesian in small to large sized farms and contributed only $2 \%$ of the total milk production of Ethiopia. This sector owns most of the country's improved dairy stock [14]. The main source of feed is both home produced and purchased hay and the primary objective is to get additional cash income from milk sale. This production system is now expanding in the highlands among mixed crop-livestock farmers and serves as the major milk supplier to the urban market [15].

\section{Urban or Commercial Dairy Production System}

Commercial or Urban dairy farming is a more specialized farming practiced in state sector and very few individuals on commercial basis. These farming systems with combination to perurban and urban small scale dairy farmers produce $2 \%$ of the total milk production of the country. Farmers use part or all of their land to grow fodder crops for their dairy cattle. The dairy animals do not 
provide draft, but their manure is used as fertilizer on crops, milk is the main source of farm income. It is mainly under taken by small farmers using family labor, but commercial farmers using herd labor also practices this system on a large scale. The herd is dominated with improved/cross breed dairy cattle and the production system is market oriented and milk production is for sales. As compared to other systems they have relatively better access to inputs (e.g. feeds) and services (e.g. artificial insemination) provided by the public and private sectors and use intensive management system. Marketing of fluid milk is arranged through direct contact between producers and consumers, and/or involves wholesalers/ processors, cooperatives, and retailers [16].

\section{Marketing Systems of Dairy and Its Products}

In Ethiopia, milk and milk products are marketed through both informal and formal marketing systems. In the dominant informal marketing system, producers sell to consumers directly or to unlicensed traders or retailers. Price is usually set through negotiation between the producer (seller) and the buyer; this system is predominant in the rural dairy production system. In the formal marketing system there are cooperatives and private milk collecting and processing plants that receive milk from producers and channel to consumers, caterers, supermarkets and retailers. Informal market involves direct delivery of fresh milk by producers to consumers in the immediate neighborhood and sale to itinerant traders or individuals in nearby towns. In Ethiopia, dairy products (fresh milk, butter, buttermilk and cottage types of cheese) are distributed through the informal and formal marketing systems. The informal market involves direct delivery of dairy products by producers to consumers in the immediate neighborhood and sales to itinerant traders or individuals in nearby towns [17]. Therefore, markets involve sales, locations, sellers, buyers and transactions [18]. According to Tsehay [12], milk-marketing group can be defined as a group of smallholder farmers who individually produce at least one liter of saleable milk and are willing to form a group with the objective of collectively processing and marketing milk [19]. In their review, indicated very useful involvement of the government of India at every step of the development for expansion of dairy cooperatives in the country for the successes of dairying and suggested that the pattern of dairy development (India) can be emulated at least around the major milk sheds in Ethiopia, for instance, around Nazareth, Dire Dawa, Harar, Bahir Dar, Jimma and Assela.

\section{Major Constraints of Milk Production}

Major constraints affecting milk production potential of dairy cattle in most parts of Ethiopia are shortage of grazing land, Infectious and parasitic diseases, shortage of land for cultivation of improved forage, inadequate veterinary service, low milk production potential of local zebu cattle, inadequate Artificial Insemination (AI) service and labor shortage. According to Kibru et al. [20], funding majority of farmers reported that shortage of grazing land was main problem of milk production followed by disease and parasites in Ethiopia. Inadequate veterinary service to handle outbreak of diseases was also prevailing constraints of milk production in the country.

\section{Environmental Stress}

Concomitant to the improvement in the quality of livestock through the crossbreeding, there has been an increase in the susceptibility of these animals to various diseases, including exotic ones. Simultaneously, a number of disease control programmes have been initiated with an aim of reducing the morbidity and mortality. Efforts have been made to control diseases, like rinderpest, footand-mouth disease, hemorrhagic septicemia, black-quarter and anthrax. Although Rinderpest has been eradicated from the country, the prevalence of other diseases continues to be a major problem. Financial constraints generally inhibit these farmers' access to the organized veterinary services and they still rely on the conventional treatment methods [20].

\section{Lack of Animal Health Protection and Control Service}

According to Gatwech [21], funding the loss of animals due to diseases was aggravate by shortage of veterinary professionals, accessibility of veterinary service and lack of adequate transport facility were the major problems. The existing of such a poor performance of veterinary service indicated that regional government give less attention to the livestock sector in general. Similar assumption was reported by [22]. In that poor performance of veterinary service in the lowlands is the outcome of the government monopolized service. Livestock keepers therefore, tend to divert to traditional ethno-veterinary practices in the villages and make use of various herbs and/or illegal drugs to treat their animals [20]. According to Azage et al. [15], funding diseases in dairy animals affect reproduction, milk production, milk quality and cause mortality and morbidity. In the rural lowland dairy production system of Mieso and Metema, disease and parasite were ranked as the major problem by most of the farmers (about 66-86\%). Mastitis, trypanosomosis, internal and external parasites, bloating anthrax and black leg reported to be a major disease affecting livestock production and productivity in the country [23].

\section{Feed Shortage}

Feed shortage in terms of quality and quantity is the major constraint regardless of the dairy Production system and agroecology. Feed constraints could be seen from different dimension in terms of quality and quantity and seasonal feed supply to meet the nutritional requirements of dairy animals. Both roughage and concentrate feeds are either too expensive or unavailable in sufficient quantity and quality to improve dairy production [22]. According to Ulfina et al. [15], funding inadequate supply of quality feed and low productivity of the indigenous cattle breeds are the major factor limiting dairy productivity in the region. According to Derese [24], funding unavailability of feed probably limit the milk production potential of cows with good milk producing ability more than any other single factor and is the most serious constraint to improve dairying. 


\section{Lack of Sufficient Landholding for Cultivation of Green Fodder}

The main feeding problem in traditional systems of cattle rearing is the lack of quality forage available in the dry season. So, pastoralists must find alternative sustainable ways of feeding as the grazing land is gradually plummeting. Fodder deficit is a major impediment for dairy development due to pressure of increasing human population [24].

\section{Poor Access to Inputs and Services}

Access to inputs and services includes extension, animal health, credit, market information, AI and dairy inputs. The inefficient AI service reported is associated with lack of sufficient facilities and trained AI technicians in the country. The problem of AI service provision seems to be a critical issue at national level. AI service in Ethiopia has not been successful to improve reproductive performance of the country's dairy industry [25].

\section{Poor Socio-economic Status of Dairy Farmers}

More than half of all cattle and almost all sheep and goats in Ethiopia belong to smallholders, who keep livestock mostly in traditional systems with livestock contributing substantially to their livelihoods and food security. These prime stakeholders of the entire value chain of milk are deprived of minimum resources of land, labour and capital etc [1].

\section{Lack of Awareness}

The cooperative sector also plays a significant role in the delivery of services though it is limited to certain regions. Most livestock services, such as artificial insemination/natural service, vaccination and de-worming, are time-sensitive, and many a times the government machinery responsible for these services fails to deliver the same in a timely manner due to financial, logistical and administrative constraints. There is also lack of trained and skilled workers who can make the dairy enterprises more viable and remunerative enterprise. The cooperative model though successful has not been able to include all the farmers into the fold. There are still many potential farmers who use the informal channel of milk sale and delivery [1].

\section{Adulteration and Food Safety}

Milk before being pooled up at the collection centre from various farms and animals are not subjected to any screening for the zoonotic diseases, adulterants and contaminants in many of the cooperative societies. This often results in spoilage of the entire batch of the pooled milk if one of the milk cans goes undetected. The most important aspect of milk processing is its purity and wholesomeness. There have been instances of cheap substitution of skimmed milk powder with below standard substances which is hazardous to health. Moreover, the farmers not being able to get fair and remunerative prices for the milk often tend to give adulterated milk at the collection centers. They often add additives to increase the fat content of the milk and get better price for the lot. Addition of vegetable fat, animal fat, starch, etc. has been quite frequent among the farmers to alter the fat and solid content of the milk [26].

\section{Milk and Milk Product Consumption in Rural Areas}

In the rural areas, the consumption of milk will be determined by livestock ownership and season. The demand for milk is mainly for fresh whole milk which is satisfied by own production or purchased from neighbors. Processed milk is currently not sold in rural markets. In the rural areas producers will consume fresh milk and will convert their milk to butter. It is estimated that $40 \%$ of the milk produced is converted to butter, while only $9 \%$ is converted to cheese. Traditional butter ferments slowly at room temperature and can be kept for a year or longer, offering rural consumers a readily storable and durable [27].

\section{Milk and Milk Product Consumption in Pastoral Areas}

Pastoral communities are acutely aware of the nutritional value of milk. Women in Somali Region perceive milk from camels and goats to be the most beneficial for children's overall health, strength, and growth. In the wet season, milk consumed by pastoral children can account for $67 \%$ of the mean daily energy they require and $100 \%$ of their protein requirements [28]. Lack of availability and access to milk in the dry season decreased daily consumption amounts by almost $25 \%$ with milk contributing only $16 \%$ and $50 \%$ of energy and protein requirements respectively. In drought years, children's milk consumption will drop an average of $50 \%$ in surveyed communities [28].

Consumption of milk within households decreases during the dry season due primarily to lack of feed and fodder resources and general decline in the nutritional health of lactating animals. Herders will often try to time cattle pregnancies and calving periods so that the natural drying off period for a lactating animal coincides with the dry season. For women and children, the shortage of dry season milk availability in pastoral communities is exacerbated because herds are moved far from settled family members as boys and men seek out water and grazing lands for their animals [27].

Ethiopia has a low level of milk consumption compared to other countries in the region (Kenya $=90 \mathrm{lt} / \mathrm{cap}$; Uganda $=50 \mathrm{lt} / \mathrm{cap}$ ). Even though Ethiopia has the largest inventory of milk producing animals, (cattle, sheep, goats and camels), per capita consumption of milk is low compared to Kenya and Sudan with fewer livestock. The national per capita consumption of milk and milk products is estimated at $17 \mathrm{~kg}$. Per capita income levels in Ethiopia place it in the range with Tanzania and Rwanda with annual per capita consumption of milk at less than $20 \mathrm{~kg}$. Average expenditures by households on milk and milk products is only four percent of the total household food budget [29].

\section{Future Prospects}

Milk production in the country has generally increased over the last 10 years from about 1.5 billion litters in 2001 to about 2.2 billion litters in 2005 and around 2.9 billion litters in 2010. This 
increasing trend is mostly associated with an increase in the number of cows. However, the per capita milk consumption has declined from $26 \mathrm{~kg}$ per annum in 1980 , to $22 \mathrm{~kg}$ in $1993,19 \mathrm{~kg}$ in 2000 and $16 \mathrm{~kg}$ in 2009 . This is likely to be attributed to the mismatch between the growth rate of milk production and human population. As is indicated in the Livestock Development Master Plan [30]. The high human population growth will drive up demand for quality consumer goods including milk and milk products as incomes improve. The principal demand will continue to be for liquid milk, much of which will be supplied through informal channels. In rural areas, consumption of milk and milk products is heavily influenced by livestock ownership/herding, while in urban areas the principal determinant of the consumption levels is income. Normally, the increase in demand for milk and milk products will be a function of rapidly rising human population, urbanization and increases in per capita income. In Addis Ababa, surveys of the different supermarkets reveal a variety of locally processed as well as imported milk products (fresh milk, pasteurized milk, UHT milk, cream, cheese, butter, butter-cook, butter-table, Gouda cheese, cottage cheese, mozzarella cheese, provolone cheese, cream cheese, fermented milk, and natural and flavored yoghurt). There is an attempt made to project the additional milk requirement to supply the growing consumer needs in Ethiopia for the coming 9-10 years [4]. To estimate the milk production, cow milk production growth rate of 4.1 percent calculated based on the figures reported by the CSA annual report for the years 2004 to 2010 was used. Milk available for consumption is estimated based on the report of [30].

\section{Conclusion}

Ethiopia has the highest livestock populations in Africa and accounts for $17 \%$ of cattle, $20 \%$ of sheep, $13 \%$ of goats and $55 \%$ of equines in Sub-Saharan Africa. Livestock production in Ethiopia is mainly of smallholder farming system with an animal having multipurpose use and accounts for approximately $30 \%$ of the total agricultural Gross Domestic Product (GDP) and 16\% of national foreign currency earnings. Ethiopia holds large potential for dairy development due to its large livestock population, the favorable climate for improved, high-yielding animal breeds, emerging market opportunity, improved policy environment for involvement of private sectors, and the relatively disease free environment for livestock In Ethiopia, milk and milk products are marketed through both informal and formal marketing systems. In the dominant informal marketing system, producers sell to consumers directly or to unlicensed traders or retailers. In the formal marketing system there are cooperatives and private milk collecting and processing plants that receive milk from producers and channel to consumers, caterers, supermarkets and retailers. In general, Ethiopia has large number of livestock but its production and productivity remains low. Therefore, it is better to mitigate feed shortage through planting improved forage through irrigation and feed storage systems for dry seasons, in addition to this use AI service to increase milk production by improving genetic potential of local dairy cattle, use modern production system with improved technology in urban area and in rural area improve traditional system through feed supplementation and better health care and make market channel to increase marketing of dairy cattle and its product.

\section{Acknowledgement}

Authors' deepest gratitude goes to friends and Debre Berhan University Staff members for their logistic supports.

\section{References}

1. CSA (2017) Agricultural Sample Survey 2016/2017: Report on Livestock and Livestock Characteristics (private peasant holdings). Addis Ababa Ethiopia 2: 9-12.

2. Ahmed MM, Ehui S, Yemesrach A (2003) Dairy development in Ethiopia. International Food Policy Research Institute, p. 58.

3. Yonad (2009) Value chain analysis of milk and milk products in Borana pastoralist area, p. 1-66

4. CSA (2011) Agricultural sample survey: Report on livestock and livestock characteristics (private peasant holdings). Addis Ababa, Ethiopia, p. 9-26.

5. FAO (2009) Food and Agriculture Organization of united nation livestock's sector brief. Ethiopia Livestock Information and Sector Analysis, p. 15-16.

6. Tesfaye Lemma Tefera, Puskur R, Hoekstra D, Azage Tegegne (2010) Commercializing dairy and forage systems in Ethiopia: An innovation systems perspective. ILRI, p. 57.

7. Getachew F, Geda G (2001) The Ethiopian dairy development policy: A draft policy document. Food and Agriculture Organization, Addis Ababa, Ethiopia.

8. Moard (2007) Livestock master plan study Phase I report volume T-sociological aspects.

9. Ketema H (2000) Dairy development in Ethiopia. In: the role of village dairy co-operative in dairy development, SDDP (Smallholder Dairy Development Project) proceedings, MOA (Ministry of Agriculture), Addis Ababa.

10. Yoseph M, Azage T, Alemu Y (2003) Evaluation of the general farm characteristics and dairy herd structure in urban and peri-urban dairy production systems in Addis Ababa Milk Shed. In: Yilma Jobre and Getachew Gebru (editors), Proceedings of the $10^{\text {th }}$ annual conference of the Ethiopian society of animal production, Addis Ababa, Ethiopia, pp. 139-144.

11. Zegeye Y (2003) Challenges and opportunities of livestock marketing in Ethiopia. In: Proceeding of the $10^{\text {th }}$ Annual Conference of Ethiopian Society of Animal Production (ESAP) 22-24 August 2002, p. 47-54.

12. Dereje (2005) Survey of traditional cattle production systems and preferred cattle functions in North and south Wollo zones, Ethiopia. Ethiopian Veterinary Journal 9(1): 91-108.

13. Tsehay R (2002) Small-Scale Milk Marketing and Processing in Ethiopia. Smallholder Dairy Production and Market Opportunity and Constraints: A South-South Workshop, Anand, p. 13-16.

14. Gebre W, Alemayehu A, Demeke M, Bediye S, Tadesse A (2000) Status of dairy development. Smallholder Dairy Development Project (SDDP) dairy research in Ethiopia. In: The role of village dairy co-operatives in dairy development. Addis Ababa, Ethiopia.

15. Azage T, Berhanu G, Dirk H, Berhanu B, Yoseph M (2013) Smallholder dairy production and marketing systems in Ethiopia: IPMS experiences and opportunities for market-oriented development. IPMS (Improving Productivity and Market Success), p. 31.

16. Siegefreid D, Berhanu A (1991) Dairy marketing in Ethiopia: Markets of first sale and producers' marketing patterns. ILCA (International Livestock Centre for Africa), Addis Ababa, Ethiopia. 
17. Debrah S, Berhanu A (1991) Dairy Marketing in Ethiopia: Markets of first sale and producers' marketing patterns. ILCA (International Livestock center for Africa), Addis Ababa, Ethiopia.

18. Berhane M, Workneh A (2003) Promotion of dairy marketing using farmer's cooperatives: Lessons from India. In: Jobre Y and Gebru G (Eds.), Challenges and opportunities of livestock marketing in Ethiopia. Proceedings of the $10^{\text {th }}$ annual conference of ESAP (Ethiopian Society of Animal Production) held in Addis Ababa, Ethiopia, p. 81-87.

19. Kibru B, Berihan T, Teka F (2015) Characterization of smallholder cattle milk production system in Aleta Chukko District, Southern Ethiopia. J Adv Dairy Res 3: 132.

20. Gatwech T (2012) Dairy production, processing and market system: A case study of Gambella, South West Ethiopia. Debre zeit, Ethiopia.

21. Tangka DK, Emerson RD, Jabbar MA (2002) Food Security effects of intensified dairying: Evidence from the Ethiopian highlands. ILRI (International Livestock Research Institute), p. 68.

22. Ulfina G, Jiregna D, Alganesh T, Shiv P, Late M (2013) Dairy production potential and challenges in Western Oromia milk value chain, Oromia, Ethiopia. Journal of Agriculture and Sustainability 2: 1-21.

\section{ISSN: 2574-1241}

DOI: 10.26717/BJSTR.2019.16.002903

Tewodros Alemneh. Biomed J Sci \& Tech Res

This work is licensed under Creative Commons Attribution 4.0 License

Submission Link: https://biomedres.us/submit-manuscript.php
23. Derese $T$ (2008) Present situation of urban and per-urban milk production and quality of raw milk produced in West Shewa Zone, Oromia Region, Ethiopia, Alemaya, Ethiopia.

24. Sinishaw W (2005) Study on semen quality and field efficiency of AI bulls kept at the National Artificial Insemination Center. Debre Zeit, Ethiopia.

25. Lipismita S, Pattanaik AK (2013) Dairy production in India-existing scenario and future prospects. International Journal of Livestock Research 4(2): 110.

26. Government of Ethiopia (2007) The Livestock Master Plan Study Report. Addis Ababa.

27. Sadler Kate, Catley Andrew (2009) Milk matters: The role and value of milk in the diets of Somali pastoralist children in Liben and Shinile, Ethiopia. 2009: 11-12.

28. Staal SJ, Pratt AN, Jabbar M (2008) Dairy Development for the Resource Poor, Part II. Kenya and Ethiopia. Dairy Development Studies, p. 52.

29. GRM International BV (2007) Livestock development master plan study: Phase I report-data collection and analysis.

30. Felleke G, Geda G (2001) The Ethiopian dairy development policy: a draft policy document. Ministry of Agriculture (MoA), Addis Ababa, Ethiopia.

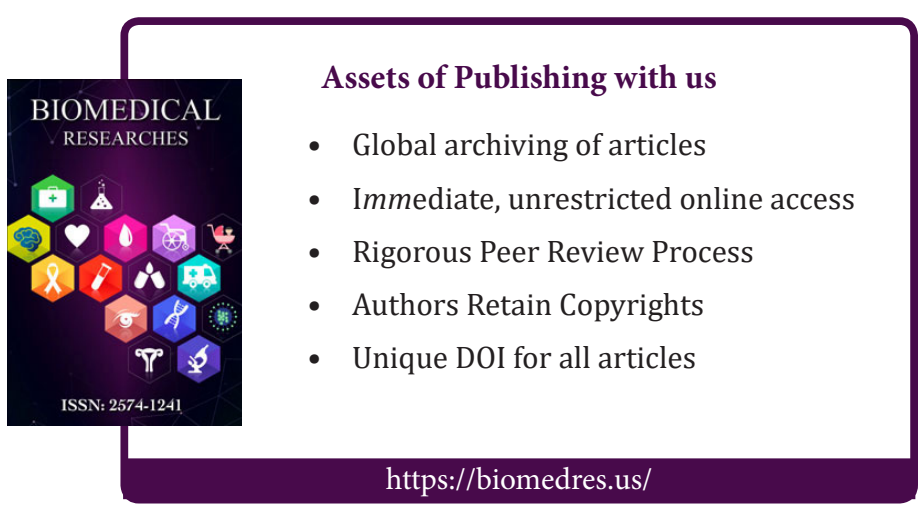

